\title{
PENGELOMPOKAN BANK DI INDONESIA BERDASARKAN INDIKATOR RASIO KEUANGAN DENGAN ANALISIS GEROMBOL
}

\author{
ELITA RAHMA PUTRI, MAIYASTRI, HAZMIRA YOZZA \\ Jurusan Matematika, \\ Fakultas Matematika dan Ilmu Pengetahuan Alam, Universitas Andalas, \\ Kampus UNAND Limau Manis Padang, Indonesia, \\ email : elitarahmaputri@yahoo.com
}

\begin{abstract}
Abstrak. Bank adalah badan usaha yang menghimpun dana dari masyarakat dalam bentuk simpanan dan menyalurkannya dalam bentuk kredit dan atau bentuk-bentuk lainnya dalam rangka meningkatkan taraf hidup rakyat banyak. Banyaknya alternatif bank yang dapat dipilih membuat nasabah cenderung lebih memilih bank yang memiliki kinerja terbaik, sehingga penggerombolan bank berdasarkan kinerjanya menjadi suatu hal penting untuk dilakukan. Tingkat kinerja bank dapat diukur dengan cara menganalisis rasio keuangannya. Metode statistik yang digunakan dalam penelitian ini adalah analisis gerombol berhirarki penggabungan. Objek yang digunakan dalam penelitian ini adalah 18 bank umum konvensional yang laporan keuangannya telah diterbitkan untuk periode September 2016. Hasil dari pengelompokan tersebut terbentuk 4 gerombol, Gerombol I diisi oleh Bank Mandiri, Gerombol III diisi oleh Bank Multiarta Sentosa, Gerombol IV diisi oleh Bank KEB Hana Indonesia dan selebihnya terletak pada Gerombol II. Gerombol yang memiliki kinerja terbaik adalah Gerombol III, diikuti Gerombol IV, Gerombol II dan Gerombol I.
\end{abstract}

Kata Kunci: Pengelompokan Bank, Analisis Gerombol, Rasio Keuangan

\section{PENDAHULUAN}

Bank adalah badan usaha yang menghimpun dana dari masyarakat dalam bentuk simpanan dan menyalurkannya kepada masyarakat dalam bentuk kredit dan atau bentuk-bentuk lainnya dalam rangka meningkatkan taraf hidup rakyat banyak [4]. Peran perbankan dalam menghimpun dana masyarakat memerlukan suatu kondisi perbankan yang sehat. Sehat tidaknya suatu perusahaan perbankan tersebut dapat dilihat dari kinerja keuangannya. Tingkat kinerja keuangan suatu perusahaan dapat diukur melalui laporan keuangan dengan cara menganalisis rasio-rasio dalam kinerja keuangannya.

Semakin banyak perusahan perbankan, maka semakin banyak tersedia alternatif bank yang dapat dipilih nasabah untuk menyimpan dananya. Di satu sisi, seorang nasabah pasti memiliki kecenderungan untuk memilih bank yang memiliki kinerja terbaik. Namun di sisi lain masyarakat umum biasanya tidak memiliki pengetahuan yang cukup baik mengenai hal itu. Jadi para nasabah perlu mencari informasi terlebih dahulu tentang tingkat kinerja bank tersebut. Hal ini bertujuan agar para nasabah merasa nyaman menyimpan dana mereka di bank. 
Untuk itu perlu dilakukan pengelompokan bank berdasarkan rasio-rasio yang telah dihitung dalam kinerja keuangannya setelah melakukan kegiatan operasional. Analisis statistik yang dilakukan untuk mengelompokan bank tersebut adalah analisis gerombol.

\section{LANDASAN TEORI}

\subsection{Jenis-Jenis Rasio Keuangan}

\section{Rasio Permodalan (Solvabilitas) [4]}

Rasio solvabilitas merupakan ukuran kemampuan bank mencari sumber dana untuk membiayai kegiatannya. Terdapat beberapa rasio solvabilitas diantaranya adalah Capital Adequancy Ratio (CAR).

CAR adalah rasio kecukupan modal yang menunjukkan kemampuan bank dalam mempertahankan modal.

\section{Rasio Rentabilitas [4]}

Rasio ini digunakan untuk mengukur tingkat efisiensi usaha dan profitabilitas yang dicapai oleh bank yang bersangkutan. Ada beberapa jenis rasio rentabilitas, yaitu :

\section{a. Return on Asset (ROA)}

Rasio ini digunakan untuk mengukur kemampuan manajemen bank dalam memperoleh keuntungan (laba sebelum pajak) yang dihasilkan dari rata-rata total aset bank yang bersangkutan.

b. Return on Equity (ROE)

Rasio ini digunakan untuk mengukur kinerja manajemen bank dalam mengelola modal yang tersedia untuk menghasilkan laba setelah pajak.

\section{c. Net Interest Margin (NIM)}

Rasio ini digunakan untuk mengukur kemampuan manajemen bank dalam mengelola aktiva produktifnya untuk menghasilkan pendapatan bunga bersih.

d. Biaya Operasional Terhadap Pendapatan Operasional (BOPO)

Rasio ini digunakan untuk mengukur kemampuan manajemen bank dalam mengendalikan biaya operasional terhadap pendapatan operasional.

\section{Rasio Likuiditas (Likuidity) [4]}

Rasio likuiditas merupakan rasio untuk mengukur kemampuan bank dalam membayar kembali pencairan dana deposannya pada saat ditagih serta dapat mencukupi permintaan kredit yang telah diajukan. Salah satu rasio likuiditas yang digunakan adalah Loan to Deposit Ratio (LDR).

Loan to Deposit Ratio (LDR) adalah rasio yang digunakan untuk menilai likuiditas suatu bank.

4. Rasio Kualitas Aset Produktif (KAP) [5]

Rasio ini digunakan untuk mengetahui kualitas aset produktif. Terdapat beberapa rasio KAP yang biasa digunakan, diantaranya adalah :

a. Aset Produktif Bermasalah dan Aset Non Produktif Bermasalah (APBANPB) Terhadap Total Aset Produktif dan Aset Non Pro- 


\section{duktif}

Rasio ini digunakan untuk mengukur besarnya jumlah aset produktif bermasalah dan aset non produktif bermasalah suatu bank terhadap total keseluruhan aset produktif dan aset non produktifnya.

b. Aset Produktif Bermasalah (APB) Terhadap Total Aset Produktif

Rasio ini digunakan untuk mengukur besarnya jumlah aset produktif bermasalah suatu bank terhadap total keseluruhan aset produktifnya.

c. Cadangan Kerugian Penurunan Nilai (CKPN) Aset Keuangan Terhadap Aset Produktif

Rasio ini digunakan untuk mengukur besarnya CKPN aset keuangan yang dibentuk bank dibandingkan total aset produktifnya.

\section{d. Non Performing Loan (NPL) gross}

Rasio ini digunakan untuk mengukur besarnya jumlah kredit bermasalah pada suatu bank dibandingkan dengan total kesuluruhan kreditnya.

e. Non Performing Loan (NPL) net

Rasio ini digunakan untuk mengukur besarnya jumlah kredit bermasalah pada suatu bank setelah dikurangi CKPN kredit dibandingkan dengan total kesuluruhan kreditnya.

\subsection{Statistika Deskriptif [10]}

Statistika deskriptif adalah metode-metode yang berkaitan dengan pengumpulan dan penyajian suatu gugus data sehingga memberikan informasi yang berguna. Penyajian hasil analisis deskriptif dapat berupa tabel, diagram, atau grafik dari ringkasan data.

\subsection{Analisis Gerombol}

Analisis gerombol merupakan suatu teknik analisis multivariat yang bertujuan untuk menggerombolkan data observasi ataupun peubah-peubah ke dalam gerombol sedemikian rupa sehingga masing-masing gerombol bersifat homogen sesuai dengan peubah yang digunakan untuk melakukan penggerombolan. [7]

Sebelum melakukan analisis gerombol, hal penting yang harus dilakukan adalah menentukan ukuran kemiripan dan ketakmiripan antar dua objek. Ukuran ketakmiripan antar unit pengamatan dalam analisis gerombol ditentukan berdasarkan ukuran jarak [8]. Ukuran jarak yang digunakan dalam penelitian ini adalah Jarak Pearson yang dapat dirumuskan sebagai berikut :

$$
d_{i j}=\sqrt{\sum_{k=1}^{p} \frac{\left(x_{i k}-x_{j k}\right)^{2}}{\operatorname{var}\left(x_{k}\right)}}
$$

dengan :

$x_{i} k=$ nilai dari objek ke- $i$ pada peubah ke- $k$

$x_{j} k \quad=$ nilai dari objek ke- $j$ pada peubah ke- $k$

$x_{k} \quad=$ peubah ke- $k$ 
Elita Rahma Putri dkk.

$\operatorname{var}\left(x_{k}\right) \quad=$ varian dari peubah ke- $k$

\subsubsection{Metode Penggerombolan}

Secara umum ada dua metode penggerombolan yaitu metode berhirarki dan metode tak berhirarki. Metode berhirarki dibagi menjadi dua yaitu penggabungan (agglomerative) dan pemecahan (divisive). Pada metode berhirarki penggabungan, $n$ objek dijadikan $n$ gerombol, yang masing-masingnya terdiri dari 1 objek. Kemudian secara bertahap gerombol yang jaraknya berdekatan digabung menjadi satu sampai akhirnya semua objek tergabung dalam satu gerombol. Setiap penggabungan disertai dengan perbaikan matriks jarak antar objek.

Terdapat beberapa metode perbaikan jarak yang dapat digunakan, beberapa diantaranya seperti yang dijelaskan berikut.

Pada setiap tahap, setelah terbentuk gerombol baru $(U V)$ yang merupakan gabungan gerombol $U$ dan $V$, maka jarak antara $(U V)$ dan gerombol lainnya, misal $W$ dapat ditentukan dengan beberapa metode dibawah ini :

a. Metode Pautan Tunggal (Single Linkage) [3]

$$
d_{(U V) W}=\min \left\{d_{U W}, d_{V W}\right\}
$$

b. Metode Pautan Lengkap (Complete Linkage) [3]

$$
d_{(U V) W}=\max \left\{d_{U W}, d_{V W}\right\}
$$

c. Metode Pautan Rataan (Average Linkage) [3]

$$
d_{(U V) W}=\frac{\sum_{i} \sum_{j} d_{i j}}{N_{U V} N_{W}}
$$

d. Metode Centroid [8]

$$
d_{(U V) W}=\frac{N_{U}}{N_{U}+N_{V}} d_{U W}+\frac{N_{V}}{N_{U}+N_{V}} d_{V W}-\frac{N_{U} N_{V}}{\left(N_{U}+N_{V}\right)^{2}} d_{U V}
$$

e. Metode Ward [8]

$$
d_{(U V) W}^{2}=\frac{N_{U}+N_{V}}{N_{U}+N_{V}+N_{W}} d_{U W}^{2}+\frac{N_{V}+N_{W}}{N_{U}+N_{V}+N_{W}} d_{V W}^{2}+\frac{N_{W}}{\left(N_{U}+N_{V}+N_{W}\right)^{2}} d_{U V}^{2}
$$

\subsection{Menentukan Kebaikan Metode Perbaikan Jarak dengan Simpangan Baku}

Untuk mengetahui metode mana yang mempunyai kinerja terbaik, dapat digunakan rasio antara rata-rata simpangan baku dalam gerombol $\left(S_{W}\right)$ dan simpangan baku antar gerombol $\left(S_{B}\right)$. Rata-rata simpangan baku dalam gerombol $\left(S_{W}\right)$ dinyatakan sebagai [1]:

$$
S_{W}=K^{-1} \sum_{k=1}^{K} S_{k}
$$

Simpangan baku antar gerombol $\left(S_{B}\right)$ dinyatakan sebagai [1]: 


$$
S_{B}=\left[(K-1)^{-1} \sum_{k=1}^{K}\left(x_{k}-\bar{x}\right)^{2}\right]^{1 / 2}
$$

Metode yang memberikan hasil penggerombolan terbaik adalah metode yang memiliki rasio antara rata-rata simpangan baku dalam gerombol $\left(S_{W}\right)$ dan simpangan baku antar gerombol $\left(S_{B}\right)$ terkecil. [7]

\section{DATA DAN METODE}

\subsection{Data}

Objek yang digunakan dalam penelitian ini adalah 18 bank umum konvensional yang terpilih menjadi Bank Terbaik Tahun 2016 versi Majalah Investor dan laporan keuangannya telah diterbitkan oleh lembaga OJK melalui website www.ojk.go.id. Bank-bank tersebut adalah : Bank Mandiri, Bank Rakyat Indonesia, Bank Tabungan Negara, Bank Himpunan Saudara 1906, BPD Bali, BPD Kalimantan Barat, BPD Kalimantan Tengah, BPD Lampung, BPD Jawa Barat dan Banten, BPD Nusa Tenggara Barat, BPD Nusa Tenggara Timur, BPD Sulawesi Selatan dan Barat, Bank Central Asia, Bank Index Selindo, Bank KEB Hana Indonesia, Bank Mayapada International, Bank Mega dan Bank Multiarta Sentosa.

Data yang digunakan dalam penelitian ini adalah data sekunder berupa laporan keuangan yang diterbitkan oleh masing-masing bank yang telah diaudit untuk periode September 2016. Adapun peubah-peubah yang diamati dalam penelitian ini adalah sebagai berikut :

$$
\begin{array}{lc}
X_{1}: \text { CAR } & X_{7}: \text { ROA } \\
X_{2}: \text { APBANPB } & X_{8}: \text { ROE } \\
X_{3}: \text { APB } & X_{9}: \text { NIM } \\
X_{4}: \text { CKPN AK } & X_{10}: \text { BOPO } \\
X_{5}: \text { NPL gross } & X_{11}: \text { LDR } \\
X_{6}: \text { NPl net } &
\end{array}
$$

\subsection{Metode Analisis}

Langkah-langkah yang dilakukan adalah sebagai berikut :

1. Melakukan analisis deskriptif untuk melihan gambaran umum data.

2. Menggerombolkan objek dengan analisis gerombol berhirarki penggabungan, dengan langkah sebagai berikut :

a. Membentuk matriks jarak antar pengamatan. Ukuran jarak yang digunakan adalah Jarak Pearson.

b. Menggabungkan gerombol yang memiliki jarak terdekat.

c. Melakukan perbaikan jarak dengan kelima metode perbaikan jarak.

d. Ulangi langkah (b) dan (c) sampai terbentuk satu gerombol besar untuk masing-masing metode perbaikan jarak.

e. Membentuk dendogram dan melakukan pemotongan pada selisih jarak terbesar.

f. Menentukan jumlah gerombol dan anggotanya untuk masing-masing metode. 
g. Menentukan metode perbaikan jarak terbaik dengan Metode Simpangan Baku.

h. Menganalisa karakteristik gerombol yang terbentuk dari metode terpilih berdasarkan rata-rata masing-masing peubah penggerombol

Analisis dilakukan dengan bantuan software statistika yaitu Minitab 17.

\section{HASIL DAN PEMBAHASAN}

\subsection{Gambaran Umum Data}

Untuk melihat keadaan masing-masing bank di Indonesia terhadap masing-masing peubah, maka dilakukan analisis deskriptif terhadap masing-masing peubah untuk semua bank yang diteliti. Dari analisis deskriptif yang dilakukan, dapat disimpulkan semakin tinggi rasio CAR, CKPN AK, ROA, ROE, dan NIM suatu bank serta semakin rendah rasio APBANPB, APB, NPL gross, NPL net, BOPO dan LDRnya maka semakin baik kinerja keuangan bank tersebut.

\subsection{Pemilihan Metode Perbaikan Jarak Terbaik}

Langkah awal dalam penggerombolan adalah menghitung jarak masing-masing objek pengamatan. Setelah dihitung jarak masing-masing objek pengamatan selanjutnya dilakukan penggerombolan dengan beberapa metode perbaikan jarak.

Untuk melihat kinerja metode digunakan kriteria dua nilai simpangan baku. Metode terbaik mempunyai nilai rasio antara rata-rata simpangan baku dalam gerombol $\left(S_{W}\right)$ dan simpangan baku antar gerombol $\left(S_{B}\right)$ yang paling kecil. Rasio simpangan baku masing-masing metode dapat dilihat pada Tabel 1 berikut :

Tabel 1. Rasio Simpangan Baku Metode Pautan Tunggal, Pautan Lengkap, Pautan Rataan, Centroid dan Ward dengan Jarak Pearson

\begin{tabular}{|c|c|l|c|c|c|c|}
\hline & No. & Metode & Banyak Gerombol & $S_{W}$ & $S_{B}$ & Rasio \\
\hline & 1 & Pautan Tunggal & 2 & 0.57 & 2.61 & 0.22 \\
\hline & 2 & Pautan Lengkap & 2 & 1.25 & 0.90 & 1.39 \\
\hline & 3 & Pautan Rataan & 4 & 0.57 & 2.07 & 0.27 \\
\hline & 4 & Centroid & 4 & 0.30 & 2.03 & 0.15 \\
\hline & 5 & Ward & 2 & 1.62 & 0.34 & 4.78 \\
\hline
\end{tabular}

Berdasarkan Tabel 1 dapat dilihat bahwa metode perbaikan jarak yang paling baik dengan menggunakan Jarak Pearson adalah Metode Centroid. Untuk selanjutnya akan dideskripsikan karakteristik masing-masing gerombol yang terbentuk dengan menggunakan metode ini.

\subsection{Analisis Gerombol dengan Metode Perbaikan Jarak Centroid}

Hasil analisis gerombol yang ditampilkan dalam bentuk dendogram untuk data yang digerombolkan dengan metode perbaikan jarak centroid disajikan pada Gambar 1 
berikut.

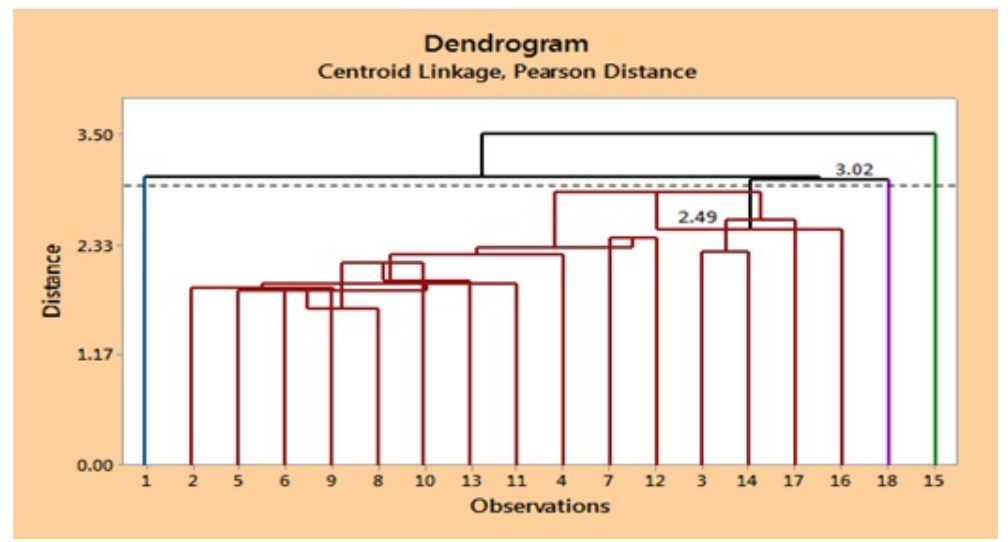

Gambar 1. Dendogram Hasil Analisis Gerombol Bank

Pada Gambar 1 dapat dilihat bahwa selisih jarak terbesar terjadi antara jarak penggabungan 2.49 dan 3.02 yaitu sebesar 0.53. Dengan pemotongan seperti ini, diperoleh empat gerombol. Gerombol I diisi oleh Bank Mandiri, Gerombol III diisi oleh Bank Multiarta Sentosa, Gerombol IV diisi oleh Bank KEB Hana Indonesia dan Gerombol II selebihnya.

Gerombol yang terbentuk akan diurutkan dari yang memiliki kinerja paling baik untuk melihat kelompok bank berdasarkan tingkat kinerja keuangannya. Untuk melihat ciri khas masing-masing gerombol, pada Tabel 2 disajikan nilai rata-rata masing-masing peubah untuk masing-masing gerombol.

Tabel 2. Rata-Rata Masing-Masing Peubah Penggerombol

\begin{tabular}{|l|l|c|c|c|c|}
\hline & Peubah & Gerombol I & Gerombol II & Gerombol III & Gerombol IV \\
\hline & CAR & 22.63 & 20.99 & 29.46 & 17.74 \\
\hline & APBANPB & 2.33 & 1.50 & 0.64 & 0.61 \\
\hline & APB & 2.93 & 1.55 & 0.62 & 0.71 \\
\hline & CKPN AK & 3.88 & 1.09 & 0.77 & 0.38 \\
\hline & NPL gross & 3.69 & 2.01 & 0.98 & 0.87 \\
\hline & NPL net & 1.04 & 1.04 & 0.73 & 0.75 \\
\hline & ROE & 13.76 & 21.57 & 6.22 & 13.10 \\
\hline & NIM & 6.40 & 7.10 & 4.22 & 3.83 \\
\hline & BOPO & 77.13 & 73.33 & 81.94 & 67.36 \\
\hline & LDR & 89.90 & 85.32 & 79.38 & 150.78 \\
\hline
\end{tabular}

Dari Tabel 2 dapat dilihat bahwa Gerombol III lebih baik daripada Gerombol I, Gerombol II dan Gerombol IV, karena memiliki rata-rata rasio CAR lebih tinggi 
serta rata-rata rasio APB, NPL net dan LDR lebih rendah dibandingkan Gerombol I, Gerombol II dan Gerombol IV. Dapat dilihat juga Gerombol IV lebih baik daripada Gerombol I dan Gerombol II, karena memiliki rata-rata rasio APBANPB, APB, NPL gross, NPL net dan BOPO lebih rendah dibandingkan Gerombol I dan Gerombol II. Gerombol II lebih baik daripada Gerombol I karena memiliki rata-rata rasio ROA, ROE dan NIM lebih tinggi serta rata-rata rasio APBANPB, APB, NPL gross, BOPO dan LDR lebih rendah dibandingkan Gerombol I.

\section{KESIMPULAN}

Berdasarkan pembahasan yang telah diuraikan, ternyata dengan metode perbaikan jarak centroid bank di Indonesia dapat dikelompokkan menjadi empat gerombol. Gerombol III yang diisi oleh Bank Multiarta Sentosa memiliki kinerja terbaik diantara gerombol lainnya berdasarkan rasio keuangannya. Gerombol IV yang diisi oleh Bank KEB Hana Indonesia memiliki kinerja keuangan lebih baik dibandingkan Gerombol I dan Gerombol II. Selanjutnya, Gerombol II yang diisi oleh Bank Rakyat Indonesia, Bank Tabungan Negara, Bank Himpunan Saudara 1906, BPD Bali, BPD Kalimantan Barat, BPD Kalimantan Tengah, BPD Lampung, BPD Jawa Barat dan Banten, BPD Nusa Tenggara Barat, BPD Nusa Tenggara Timur, BPD Sulawesi Selatan dan Barat, Bank Central Asia, Bank Index Selindo, Bank Mayapada International, dan Bank Mega memiliki kinerja keuangan lebih baik daripada Gerombol I yang diisi oleh Bank Mandiri. Jadi, gerombol yang memiliki kinerja keuangan terbaik berdasarkan rasio keuangannya adalah Gerombol III, diikuti Gerombol IV, Gerombol II dan Gerombol I.

\section{Daftar Pustaka}

[1] Bunkers, M.J., J.R. Miller and A.T. Degaetano. 1996. Definition of Climate Regions in the Northern Plains Using an Objective Cluster Modification Technique. J. Climate. 9: 130-146

[2] Harahap, S.S. 2009. Analisis Kritis Atas Laporan Keuangan. Raja Grafindo Persada, Jakarta

[3] Johnson, R.A. and D.W. Winchern. 1998. Applied Multivariate Statistical Analysis Ed-4. Prentice Hall Inc, New Jersey

[4] Kasmir, S.E., MM. 2000. Manajemen Perbankan. Raja Grafindo Persada, Jakarta

[5] Kuncoro, Mudrajad dan Suhardjono. 2002. Manajemen Perbankan Teori dan Aplikasi. Fakultas Ekonomi UGM, Yogyakarta

[6] Otoritas Jasa Keuangan. 2016. Laporan Publikasi Triwulanan Bank Umum Konvensional Perhitungan Rasio Keuangan September 2016. www.ojk.go.id, 27 November 2016

[7] Santoso, S. 2010. Statistik Multivariat Konsep dan Aplikasi dengan SPSS. Elex Media Komputindo, Jakarta

[8] Sartono, B., dkk. 2003. Analisis Peubah Ganda. IPB Press, Bogor

[9] Sutanto, H.T. 2009. Cluster Analysis. FMIPA UNY, Yogyakarta

[10] Walpole, R.E. 1995. Pengantar Statistika Edisi ke-3. Gramedia Pustaka Utama, Jakarta 